Charles E. Smith MD FRCPC,

Francois Donati PhD MD FRCPC, David R. Bevan MB MRCP FFaRCS

\title{
Cumulative dose- response curves for atracurium in patients with myasthenia gravis
}

The potency of atracurium was determined in five patients with moderate to severe generalized myasthenia gravis undergoing thymectomy. Train-of-four stimulation was applied to the uinar nerve and the force of contraction of the adductor pollicis was measured. Cumulative dose-response curves were obtained during thiopentone-nitrous oxide-fentanyl anaesthesia. The average time to complete the dose-response studies was $12.7 \pm$ 1.5 minutes. The ED5O, ED90 and ED95 of atracurium were (mean $\pm S E M$ ) $0.07 \pm 0.01,0.12 \pm 0.22$, and $0.14 \pm 0.04$ $\mathrm{mg} \cdot \mathrm{kg}^{-1}$, respectively. The time to 25 per cent first twitch recovery was $35 \pm 4$ min following maximum blockade. Ten normal patients were studied in the same manner. Their ED50, $E D 90$ and ED95 were $0.13 \pm 0.01,0.21 \pm 0.02$ and $0.24 \pm$ $0.03 \mathrm{mg} \cdot \mathrm{kg}^{-1}$, respectively. These results demonstrated that, in patients with moderate to severe generalized myasthenia gravis, atracurium was 1.7-1,9 times as potent as in normal individuals.

Key words

PHARMACOLOGY: dose-response curves; NEUROMUSCULAR RELAXANTS: atracurium: COMPLICATIONS: myasthenia gravis.

From the Departments of Anaesthesia, Royal Victoria Hospital, and McGill University, Montreal, Canada.

Address correspondence to: Dr. C.E. Smith, Cardiothoracic Anesthesia, G3, Cleveland Clinic Foundation, 9500 Euclid Ave, Cleveland, Ohio 44195-5076.
Myasthenia gravis is an acquired autoimmune disease associated with acetylcholine receptor deficiency at the motor end-plate. ${ }^{1-3}$ This deficiency is thought to be due to circulating acetylcholine receptor antibodies that result in the deposition of immune complexes (IgG and complement) on the post-synaptic membrane of the neuromuscular junction. ${ }^{4-8}$

It is generally accepted that patients with myasthenia gravis may exhibit increased sensitivity to competitive nondepolarizing muscle relaxants. ${ }^{9-11}$ However, the response to atracurium besylate in these patients is quite variable, probably due to differences in severity of disease, concurrent drug therapy and methodology employed..$^{12-19}$ The present study was designed to determine the potency of atracurium in patients with myasthenia gravis undergoing elective thymectomy using a cumulative dose-response technique.

\section{Methods}

After institutional approval and informed consent, five patients scheduled for elective thymectomy were studied. One hour before the scheduled surgery, patients received diazepam $0.1 \mathrm{mg} \cdot \mathrm{kg}^{-1} \mathrm{PO}$, and their usual oral dose of pyridostigmine and/or prednisone. After placement of an electrocardiograph, automatic blood pressure cuff and intravenous cannula, anaesthesia was induced with thiopentone, $3-5 \mathrm{mg} \cdot \mathrm{kg}^{-1}$ and maintained with nitrous oxide 66 per cent in oxygen and supplemental doses of thiopentone $0.5-1.0 \mathrm{mg}$ per $\cdot \mathrm{kg}^{-1}$ and fentanyl $1-2$ $\mu \mathrm{g} \cdot \mathrm{kg}^{-1}$ as required. Ventilation was provided with a bag and mask to maintain end-tidal $\mathrm{PCO}_{2}$ between 30 and $35 \mathrm{mmHg}$ (mass spectrometer). No volatile agent was given.

The ulnar nerve was stimulated supramaximally at the elbow with four square wave impulses $0.2 \mathrm{~ms}$ in duration delivered at a frequency of two $\mathrm{Hz}$ every 12 seconds using a Grass S48 stimulator and SIU 5 isolation unit. The hand and forearm were immobilized in a splint. The evoked force of contraction of the adductor pollicis muscle was measured with a Grass FT 10 force displacement transducer and recorded on paper. After stabilization of muscle twitch, cumulative doses of atracurium were administered 
TABLE I Preoperative clinical characteristics of five patients with myasthenia gravis (means \pm SEM are given below)

\begin{tabular}{|c|c|c|c|c|c|c|}
\hline $\operatorname{Sex}$ & $\begin{array}{l}\text { Age } \\
\text { (yrs) }\end{array}$ & $\begin{array}{l}\text { Weight } \\
(\mathrm{kg})\end{array}$ & $\begin{array}{l}\text { Height } \\
(\mathrm{cm})\end{array}$ & $\begin{array}{l}\text { Duration of } \\
\text { myasthenia } \\
\text { (months) }\end{array}$ & $\begin{array}{l}\text { Current } \\
\text { treatment } \\
\left(\mathrm{mg} \cdot d a y^{-1}\right)\end{array}$ & $\begin{array}{l}\text { Other } \\
\text { therapy }\end{array}$ \\
\hline M & 57 & 84 & 84 & 182 & $\begin{array}{l}\text { Pyridostigmine } 180 \\
\text { Prednisone } 60\end{array}$ & $\begin{array}{l}\text { Cimetidine } \\
\text { Digoxin } \\
\text { Moduret }\end{array}$ \\
\hline $\mathbf{M}$ & 20 & 55 & 163 & 26 & $\begin{array}{l}\text { Pyridostigmine } 180 \\
\text { Plasmapheresis }\end{array}$ & None \\
\hline $\mathbf{M}$ & 53 & 91 & 173 & 22 & $\begin{array}{l}\text { Pyridostigmine } 240 \\
\text { Prednisone } 40\end{array}$ & Cimetidine \\
\hline$F$ & 55 & 83 & 155 & 7 & $\begin{array}{l}\text { Pyridostigmine } 480 \\
\text { Plasmapheresis }\end{array}$ & $\begin{array}{l}\text { Metoprolol } \\
\text { Slow K } \\
\text { Hydrochlorothiazide }\end{array}$ \\
\hline$F$ & 63 & 54 & 163 & 10 & $\begin{array}{l}\text { Pyridostigmine } 240 \\
\text { Prednisone } 40\end{array}$ & None \\
\hline & $50 \pm 8$ & $73 \pm 8$ & $167 \pm 5$ & $18 \pm 4$ & \multicolumn{2}{|c|}{ Pyridostigmine $264 \pm 56$} \\
\hline
\end{tabular}

until at least 95 per cent first twitch (T1) depression was observed. Each drug increment was given only after the effect of the previous dose had reached a stable response defined as three equal consecutive first twitches. The initial dose of atracurium was $0.05 \mathrm{mg} \cdot \mathrm{kg}^{-1}$. The incremental doses were 0.025 or $0.05 \mathrm{mg} \cdot \mathrm{kg}^{-1}$, depending on the response to the initial dose.

After maximal neuromuscular block, the patients' tracheas were intubated and isoflurane was introduced (end-tidal concentration $0.5-1.5$ per cent as measured by a mass spectrometer). The operative procedure was then allowed to commence. No further muscle relaxant was given. Neuromuscular monitoring was continued throughout the procedure. Recovery of $\mathrm{T} 1$ and train-offour ratio (T4/T1) following maximal neuromuscular blockade was noted. At the end of the surgical procedure, isoflurane and nitrous oxide were discontinued, and 100 per cent oxygen was administered. Reversal agents were not administered. If the patients were awake, cooperative, breathing well, and could sustain a head lift, their tracheas were extubated.

First twitch responses for the adductor pollicis muscle were compared with control values to construct doseresponse curves. Linear regressions were obtained between the logit transformation of $\mathrm{T} 1$ depression at the adductor pollicis and log dose using the method of least-squares analysis ${ }^{20}$ A regression line was calculated for each patient, from which a mean dose-response curve was constructed. The calculated doses expected to produce 50,90 and 95 per cent $\mathrm{T} 1$ depression (ED50, ED 90 , ED95) and their standard errors were determined from the regression. The results were compared with those obtained for atracurium in ten normal individuals using the same cumulative dose technique during thiopentonefentanyl-nitrous oxide anaesthesia. ${ }^{21}$ In the case of normal patients, however, the initial dose of atracurium was $0.1 \mathrm{mg} \cdot \mathrm{kg}^{-1}$, followed by $0.05 \mathrm{mg} \cdot \mathrm{kg}^{-1}$. Results are expressed as mean values \pm SEM.

\section{Results}

All patients were suffering from moderate to severe generalized myasthenia (Osserman grade 2B) ${ }^{22}$ which was characterized by moderate to severe skeletal and bulbar involvement in the absence of respiratory crises. In addition to pyridostigmine therapy, four of the five patients were treated with oral steroids, and two received preoperative plasmapheresis. Patient information is summarized in Table I.

A total of three to four doses of atracurium was required to achieve 95 per cent or greater T1 depression. Maximum effect from the initial dose occurred within five minutes after its injection and within three minutes after the subsequent doses. The average time to complete the dose-response studies was $12.7 \pm 1.5 \mathrm{~min}$. In normal individuals, this time was $10.2 \pm 0.8 \mathrm{~min}$, which required three to four doses of atracurium. Patients with myasthenia gravis were 1.7 to 1.9 times more sensitive to atracurium than normal individuais (Figure). The regression lines were parallel (slope $=4.40 \pm 0.50$ myasthenia versus $4.85 \pm 0.27$ normal individuals). The potency estimates derived from the regression from patients with myasthenia gravis and normal individuals are compared 




FIGURE Dose-response relationships for atracurium in patients with myasthenia gravis ( $n=5$, cumulative dose technique) and in normal individuals ( $n=10$, cumulative dose technique). ${ }^{21}$ The logit transformation of first twitch depression is plotted as a function of the logarithm of the dose. Error bars represent SEM.

in Table II. The recovery characteristics are summarized in Table III. It was not possible to monitor recovery of the adductor pollicis in all patients due to surgical positioning. The recovery index (25-75 per cent $T 1$ recovery) was 19 \pm 6 minutes. The tracheas of all patients were extubated at the conclusion of surgery while still in the operating room. The average duration of surgery was $106 \pm 2.4$ minutes. The postoperative courses were uneventful.

\section{Discussion}

This study demonstrated the increased sensitivity of patients with myasthenia gravis to the nondepolarizing muscle relaxant atracurium. This is presumably due to the deficiency of acetylcholine receptors at the neuromuscular junction. ${ }^{1}$ Acetylcholine receptor deficiency may result from complement mediated lysis of the junctional folds on the postsynaptic membrane of the motor end plate, accelerated internalization and destruction of the acetylcholine receptor cross linked by antibody (modula-

TABLE II Potency estimates of atracurium in five patients with myasthenia and 10 normal individuals ${ }^{21}$ (means \pm SEM)

\begin{tabular}{lll}
\hline & Myasthenia & Normals \\
\hline ED50 $\left(\mathrm{mg} \cdot \mathrm{kg}^{-1}\right)$ & $0.07 \pm 0.01$ & $0.13 \pm 0.01$ \\
ED90 $\left(\mathrm{mg} \cdot \mathrm{kg}^{-1}\right)$ & $0.12 \pm 0.02$ & $0.21 \pm 0.02$ \\
ED95 $\left(\mathrm{mg} \cdot \mathrm{kg}^{-1}\right)$ & $0.14 \pm 0.04$ & $0.24 \pm 0.03$ \\
\hline
\end{tabular}

TABLE III Time to achieve recovery (first twitch- TI and train-offour-T4/T1) following maximal atracurium blockade in myasthenic patients (means \pm SEM)

\begin{tabular}{llll}
\hline TI/Contro & T4ITI & Time (min) & $\begin{array}{l}\text { Number of } \\
\text { patients }\end{array}$ \\
\hline $5 \%$ & 0 & $24 \pm 4$ & 4 \\
$10 \%$ & 0 & $28 \pm 4$ & 4 \\
$25 \%$ & $23 \pm 4$ & $35 \pm 4$ & 3 \\
$50 \%$ & $45 \pm 6$ & $43 \pm 5$ & 3 \\
$75 \%$ & $71 \pm 2$ & $55 \pm 4$ & 2 \\
$90 \%$ & $74 \pm 6$ & $66 \pm 2$ & 2 \\
$95 \%$ & $82 \pm 9$ & $75 \pm 6$ & 2 \\
\hline
\end{tabular}

tion), and to a lesser degree by antibodies which block the binding of acetylcholine to the acetylcholine receptor. ${ }^{2-6,23-25}$

The ED90 estimates obtained in this study were somewhat lower than those obtained by Baraka and Dajani in patients with myasthenia gravis undergoing thymectomies. ${ }^{2}$ In their study of three patients, the cumulative dose of atracurium required to abolish the fourth to second twitch of the train-of-four (which corresponds to approximately $75-90$ per cent block) ranged from 0.09 to 0.21 $\mathrm{mg} \cdot \mathrm{kg}^{-1}$. On the other hand, the ED90 obtained in the present study $\left(0.12 \mathrm{mg} \cdot \mathrm{kg}^{-1}\right)$ was greater than in previous case reports describing the use of atracurium in patients with myasthenia. For example, Bell et al. ${ }^{15}$ found that, in four of five patients studied, atracurium 0.1 $\mathrm{mg} \cdot \mathrm{kg}^{-1}$ was sufficient to produce abolition of twitch response during thiopentone-fentanyl-nitrous oxide anaesthesia. However, the difference in potency may partly be because their patients did not receive their anticholinesterase therapy on the moming of surgery and only received two-thirds of their usual oral dose of pyridostigmine the evening before surgery, whereas all patients in the present study received their usual oral dose of pyridostigmine up to and including the morning of surgery. The patient in Ramsey and Smith's study also exhibited increased sensitivity to atracurium compared with our patients, with complete neuromuscular blockade occurring after two minutes with only $0.06 \mathrm{mg} \cdot \mathrm{kg}^{-1}$ of atracurium ${ }^{17}$. However, succinylcholine had been employed for tracheal intubation which may have altered the sensitivity of their patient's neuromuscular junction. Vacanti et al. ${ }^{16}$ reported two myasthenic patients who were given cumulative doses of atracurium. One required $0.35 \mathrm{mg} \cdot \mathrm{kg}^{-1}$ while the other needed only $0.05 \mathrm{mg} \cdot \mathrm{kg}^{-1}$ for 90 per cent blockade. Our results lie between these two extremes.

The cumulative dose-response technique is extremely helpful in evaluating the potency of neuromuscular blocking agents. ${ }^{26,27}$ The technique is especially well suited for determining dose-response relationships in 
patients with neuromuscular abnormalities such as myasthenia gravis, since a dose-response curve can be obtained in a single individual ${ }^{28}$ and, therefore, fewer patients are required to produce statistically reliable potency estimates. The cumulative dose-response technique may underestimate potency due to the relatively rapid elimination and/or redistribution of atracurium during administration of incremental doses. ${ }^{29,30}$ For atracurium, the ED50 and ED95 can be calculated to be 14 per cent and 26 per cent greater with cumulative compared with single dose-response curves. ${ }^{21}$ However, because the duration of the study and the number of doses given were approximately the same in myasthenics and in normals, the error involved is likely to be the same in both groups. Thus, although the actual values of EDS0 and ED95 might have been slightly lower than reported here, this would not alter the potency ratio between myasthenics and normals.

The spontaneous recovery of neuromuscular function following greater than 95 per cent $\mathrm{T} 1$ depression with atracurium in the present study was similar to that of normal individuals who received the same anaesthetic. $^{31,32}$ The recovery index ( 25 to 75 per cent recovery of T1) was $17 \mathrm{~min}$ in our patients compared with $21 \mathrm{~min}$ in normal individuals under isoflurane-nitrous oxide anaesthesia. ${ }^{31}$ This indicates that once recovery starts, time to return to full neuromuscular function is not prolonged in myasthenics. All patients in the study recovered neuromuscular function spontaneously without the need for reversal agents, and were able to be extubated at the end of the surgical procedure. The fact that no patient in the present study required postoperative ventilatory support is in agreement with the scoring criteria of Leventhal et al. ${ }^{32}$ who applied multivariate discriminant analysis retrospectively to preoperative physical, historical and laboratory data of 24 myasthenic patients in order to identify risk factors that would predict the need for postoperative mechanical ventilation. None of the patients in the present study had any preoperative risk factor. For example, the duration of myasthenia gravis was $7-26$ months, the total daily dose of pyridostigmine was $180-480 \mathrm{mg}$ and no patient had any history of respiratory disease or evidence of impaired vital capacity.

Although the clinical course of myasthenia gravis can vary greatly between patients due to severity of the disease process and the response to drug therapy, the present study suggests that atracurium is $1.7-1.9$ times more potent in patients with moderate to severe generalized myasthenia gravis compared with normal individuals. We conclude that atracurium may be safely employed for muscle relaxation in patients with myasthenia. However, since the potency of atracurium is increased in these patients, and the duration of action may be slightly prolonged, clinical monitoring of neuromuscular function is strongly recommended.

\section{Acknowledgement}

Special thanks to Mrs. J. Folkers for preparing the manuscript.

\section{References}

1 EngelAG, Sahashi K, Fumagalli $G$. The immunopathology of acquired myasthenia gravis. Ann NY Acad Sci 1981; 377: 158-74.

2 Drachman DB. Myasthenia gravis (Part I). N Engl J Med 1978; 298: 136-42.

3 Drachman DB. Myasthenia gravis (Part II). N Engl J Med 1978; 298: 186-93.

4 Engel, AG, Santa T. Histometric analysis of the ultrastructure of the neuromuscular junction in myasthenia gravis and in the mysasthenic syndrome. Ann NY Acad Sci 1971; 183: 46-63.

5 Engel, AG, Lambert EH, Howard FM. Immune complexes ( $\mathrm{IgG}$ and $\mathrm{C} 3$ ) at the motor end plate in myasthenia gravis. Ultrastructural and light microscopic localization and electrophysiologic correlations. Mayo Clin Proc 1977; 52: 267-80.

6 Drachman DB, Adams RN, Josifek LF, Pestronk A, Stanley ES. Antibody-mediated mechanisms of Ach receptor loss in myasthenia gravis: clinical relevance. Ann NY Acad Sci 1981; 377: 175-88.

7 Lindsrrom $J M$, Seybold ME, Lennon VA, Whittingham S, Duane $D D$. Antibody to acetylcholine receptor in myasthenia gravis: prevalence, clinical correlates, and diagnostic value. Neurology 1976; 26: 1054-9.

8 WaltonJ. Brain's diseases of the nervous system. Myasthenia Gravis: Oxford: Oxford University Press, 1985; $567-74$.

9 Lake CL. Curare sensitivity in steroid treated myasthenia gravis: a case report. Anesth Analg 1978; 57: 132-4.

10 Buzello $W$, Noeldge $G$, Krieg $N$, Brobmann $G F$. Vecuronium for muscle relaxation in patients with myasthenia gravis. Anesthesiology 1986; 64: 507-9.

11 Loh L. Neurological and neuromuscular disease. $\mathrm{Br} J$ Anaesth 1986; 58: 190-200.

12 Baraka A, Dajani $A$. Atracurium in myasthenics undergoing thymectomy. Anesth Analg 1984; 63: 1127-30.

13 Ward $S$, Wright $D J$. Neuromuscular blockade in myasthenia gravis with atracurium besylate. Anaesthesia 1984; 39: 51-3.

14 Macdonald AM, Keen RI, Pugh ND. Myasthenia gravis and atracurium. A case report. $\mathrm{Br} J$ Anaesth 1984; 56: 651-4.

15 Bell CF, Florence AM, Hunter JM, Jones RS, Uning $J E$. Atracurium in the myasthenic patient. Anaesthesia 1984; 39: 961-8. 
16 Vacanti $C A, A l i H H$, Schweiss $J F$, Scott RP. The response of myasthenia gravis to atracurium. Anesthesiology 1985; 62: 692-4

17 Ramsey FM, Smith GD. Clinical use of atracurium in myasthenia gravis: a case report. Can Anaesth Soc J 1985; 32: 642-5.

18 Murphy DF, Magner JB. Neuromuscular blockade with atracurium besylate in a patient with myasthenia gravis. Ir J Med Sci 1986; 155: 202-3.

19 Greene SJ, Shanks CA, Ronai AK, Ramseur A. Atracurium-induced neuromuscular blockade in five myasthenic patients. Anesth Analg 1985; 64: 221.

20 Norman J. Drug-receptor reactions. Br J Anaesth 1979; 51: 595-601.

21 Smith $C E$, Donati $F$, Bevan DR. Cumulative doseresponse with infusion: a new technique to determine neuromuscular blocking potency of atracurium and vecuronium. Clin Pharmacol Ther 1988; 44: 56-64.

22 Osserman $K E$, Jenkins $G$. Studies in myasthenia gravis: review of a twenty-year experience in over 1200 patients. M Sinai J M 1971; 38: 497-537.

23 Nastuk WL, Plescia O, Osserman KE. Changes in serum complement activity in patients with myasthenia gravis. Proc Soc Exp Biol Med 1960; 105: 177-4.

24 Fambrough DM, Drachman DB, Saryamurti S. Neuromuscular junction in myasthenia gravis: decreased acetylcholine receptors. Science 1973; 182: 293.

25 Engel $A G$, Lindstrom $J M$, Lambert EH, Lennon VA. Ultrastructural localization of the acetylcholine receptor in myasthenia gravis and in its experimental autoimmune model. Neurology 1977; 27: 307-15.

26 Donlon JV, Savarese JJ, Ali HH, Teplik RS. Human dose response curves for neuromuscular blocking drugs: a comparison of two methods of construction and analysis. Anesthesiology 1980; 53: 161-6.

27 Donlon JV, Ali HH, Savarese JJ. A new approach to the study of four non-depolarizing relaxants in man. Anesth Analg 1974; 53: 934-8.

28 Laycock JRD, Smith CE, Donati F, Bevan DR. Sensitivity of the adductor pollicis and diaphragm muscles to atracurium in a hemiplegic patient. Anesthesiology 1987; 67: 851-3.

29 Gramstad $L$, Lilleaasen $P$. Dose-response relation for atracurium, ORG NC45 and pancuronium. Br J Anaesth 1982; 54: 647-51.

30 Gibson FA, Mirakhur RK, Lavery GG, Clarke RSJ. Potency of atracurium: a comparison of single dose and cumulative dose techniques. Anesthesiology 1985; 62: 657-9.
31 de Bros FM, Lai A, Scott $R$ et al. Pharmacokinetics and pharmacodynamics of atracurium during isoflurane anesthesia in normal and anephric patients. Anesth Analg 1986; 65: 743-6.

32 Leventhal SR, Orkin FK, Hirsh RA. Prediction of the need for postoperative mechanical ventilation in myasthenia gravis. Anesthesiology 1980; 53: 26-30.

\section{Résumé}

On a érudie la relation dose-effet de l'atracurium chez cing sujets atteints de myasthénie grave subissant une thymectomie. On a enregistré la force de contraction de l' adducteur du pouce suire à l'application d'une stimulation en train-de-quatre apliquée au nerf cubital, pendant une anesthésie au thiopental, protoxyde d' azote et fentanyl. On a donné des doses successives d'atracurium pendant une période de $12.7 \pm 1.5$ minutes, pour étudier la relation dose-effet. Les DASO, DA90 et DA95 étaient de (moyenne $\pm E T M) 0,07 \pm 0,01,0,12 \pm 0,02$ et $0,14 \pm 0,04$ $\mathrm{mg} \cdot \mathrm{kg}^{-1}$, respectivement. Le temps entre le bloc maximum et 25 pour cent de récupération du premier nwitch était de $35 \pm 4$ minutes. On a étudié dix sujets normaux de la même manière. Leur DA50, DA90 et DA95 s'établissaient d̀ 0,13 $\pm 0,01,0,21$ \pm 0.02 et $0,24 \pm 0,03 \mathrm{mg} \cdot \mathrm{kg}^{-1}$, respectivement. On en conclut que l'atracurium est de 1.7 a 1,9 fois plus efficace chez les myasthéniques modérés à graves que chez les sujets normaux. 